\title{
Author's index of Militaria/ Outeursindeks van Militaria (1969-1984)
}

\section{Compiled by: Opgestel deur:}

\section{Anonymous}

1. A short history of the Base Post Office, Durban (1940-1946), 2/6 (1970), pp 52-68.

2. First Annual Report of the Board of Control SATS 'General Botha', year ending 14 July, 1922, 3/1 (1971), pp 81-100.

3. Annual Report on the Transvaal Volunteers and Cadets for the year 1910-1911, 3/3 (1972), pp 76-108.

4. Ministers van Verdediging (foto's), 9/2 (1979), pp 2-3.

5. Sekretarisse van Verdediging (foto's), 9/2 (1979), pp 4-5.

6. Hoofde van die SAW (foto's), 9/2 (1979), pp 6-8.

7. Hoofde van die SA Leër (foto's) 9/2 (1979), pp 9-12.

8. Hoofde van die SA Lugmag (foto's), 9/2 (1979), pp 13-15.

9. Chiefs of the Navy (foto's), 9/2 (1979), pp $16-17$

10. SA Lugmag/Air Force (foto's), 9/2 (1979), $p$ 18.

11. SA Vloot/Navy (foto's), 9/2 (1979), p 19.

12. South Africa at war (photographs), 9/2 (1979), pp 20-21.

13. Suidwes-Afrika, 1914-1915 (foto's), 9/2 (1979), pp 22-23.

14. German East Africa, 1916 (photographs), 9/2 (1979), pp 24-25.

15. Delville Wood (photographs), 9/2 (1979), pp $26-27$.

16. Oos-Afrika, 1940-1941 (foto's), 9/2 (1979), pp 28-29.

17. Noord-Afrika, 1941-1943 (foto's), 9/2 (1979), pp 30-31.

18. Italy, 1944-1945 (photographs), 9/2 (1979), p 32.

19. Madagascar, 1942 (photographs), 9/2 (1979), pp 33.

20. Korea, 1950-1953 (foto's), 9/2 (1979), pp 34-35.

21. Angola, 1975 (foto's), 9/2 (1979), pp 36-37.

22. South West Africa - military help to the inhabitants of South West Africa (photographs) 9/2 (1979), pp 38-39.
23. Military customs and traditions/Militêre gewoontes en tradisies, 11/3 (1981), pp 38-40.

24. Military customs and traditions/Militêre gewoontes en tradisies, 11/4 (1981), pp 34-39.

25. Militêre gewoontes en tradisies/Military customs and traditions, 12/1 (1982), pp 32-34.

26. Republic Day (photographs), 12/2 (1982), pp 52-55.

27. Military customs and traditions/Militêre gewoontes en tradisies, 12/3 (1982), pp $51-53$.

28. Militêre gewoontes en tradisies/Military customs and traditions, 12/4 (1982), pp 44-46.

29. Die SAW en bewaring/The SADF and conservation, 13/1 (1983), pp 35-37.

30. The SADF and conservation/Die SAW en bewaring 13/2 (1983), pp 66-69.

31. Die SAW en bewaring/The SADF and conservation 13/3 (1983), p 61.

32. Die SAW se rol in SWA, 14/1 (1984), pp 37-41.

33. Die Gedenkmuur, 1 Valskermbataljon, 14/2 (1984), pp 30-31.

34. World War I/Eerste Wê reldoorlog, 1914-1918 (photographs/foto's), 14/3 (1984), p 1.

35. Rebellion and home front/Rebellie en tuisfront, 1914-1915 (photographs/foto's), 14/3 (1984), pp 2-6.

36. German South West Africa/Duits SuidwesAfrika, 1915-1916 (photographs/foto's), 14/3 (1984), pp 7-20.

37. German East Africa/Duits Oos-Afrika, 1916-1918 (photographs/foto's), 14/3 (1984), pp 21-27.

38. Middle East/Midde-Ooste, 1916-1917 (photographs/foto's), 14/3 (1984), pp 28-29.

39. France/Frankryk, 1916-1918 (photographs/foto's), 14/3 (1984), pp 30-32.

40. Conditions on the Western front/Toestande aan die Wesfront (photographs/foto's), 14/3 (1984), pp 33-63.

41. Peace and aftermath/Vrede en nawerking (photographs/foto's), 14/3 (1984), pp $64-65$. 
42. Die Exerce Perfectioni standbeeld, 14/4 (1984), p 62.

\section{ADLAM, A.M.}

1. Die pers as bron oor die geskiedenis van die Eerste Vryheidsoorlog, 11/1 (1981), pp 62-68.

\section{Afdeling Godsdienstige Publikasies}

\section{KAPELAAN-GENERAAL}

1. Die kapelaan: in diens met die swaard van die Heilige Gees, 13/4 (1983), pp 45-47.

\section{ALBERTSE, P.J.}

1. Short history of no 3 Squadron, SAAF, 2/1 (1970), pp 11-113.

\section{ALEXANDER, McGILL}

1. The military use of animals in South Africa (1400-1881), 7/4 (1977), pp 45-54.

2. The transport glider, $10 / 2$ (1980), pp 35-40.

\section{BARRON, G.K.B.}

1. The contribution made by T.E. Lawrence to the theory of revolutionary warfare, 13/4 (1983, pp 48-53.

\section{BARKER, W.H.}

1. Roti-operational intructional systems model, 10/3 (1980), pp 61-67.

\section{BERGH, A.C.}

1. Short history of No 25 Squadron, SAAF, 2/1 (1970), pp 118-121.

2. Die ontstaan van Vrouelugverenigings in Suid-Afrika voor die Tweede Wêreldoorlog, 9/13 (1979), pp 24-37.

3. Die geskiedenis van Afdeling Logistiek, 12/2 (1982), pp 62-66.

\section{BIERMANN, $\mathrm{H}$.}

1. Two little red shoes in no-man's-land, $11 / 3$ (1981), pp 41-44.

\section{BISSET, W.M}

1. Unexplored aspects of South Africa's First World War history, 6/3 (1976), pp 55-61.

2. New light on South Africa's naval heritage, 7/4 (1977), pp 38-44.

3. South Africa's first anti-aircraft guns, 8/1 (1978), pp 22-23.

4. A new look at the Castle of Good Hope and its symbolic importance, 9/3 (1979), pp $1-6$.
5. A short history of Fort Wynyard. Table Bay Defences, 9/4 (1979), pp 49-54.

6. UCT in uniform, 10/1 (1979), pp 23-27.

7. Die uniformknope van die Suid-Afrikaanse Vloot en sy voorgangers, 10/4 (1980), pp 39-41.

8. A short history of the development of South Africa's naval uniform, 11/2 (1981), pp 38-46.

9. The Rieder automatic rifle attachment, 11/3 (1981), pp 47-51.

10. Lower North Battery defended port of Simon's Town, 11/4 (1981), pp 29-33.

11. South African naval personnel seconded to the Royal Navy during the Second World War 1939-1945, 12/1 (1982), pp 10-26.

12. Some garrison and command regimental sergeant majors at the Castle of Good Hope in Cape Town, $12 / 4$ (1982), pp 41-43.

13. Cape Town's Timeguns, 14/4 (1984), pp 67-71.

BLOOM, J.B.

1. Ethnicity and ethnic revivalism internationally and in Africa today, 13/2 (1983), pp 19-33.

2. Pacifism and the military - a perspective, 13/3 (1983), pp 1-22.

3. Stress in the military - a perspective, $14 / 4$ (1984), pp 5-20.

BOSHOFF, A.

1. Die Christen en oorlog, 14/2 (1984), pp $1-8$.

\section{BOTHA, H.J.}

1. Die moord op Derdepoort, 25 November 1899. Nie-blankes in oorlogsdiens, 1/2 (1969), pp 3-98.

2. Historiese oorsig van die ontstaan en ontwikkeling van die militêre lugvaart en die selfstandige lugmagte, $2 / 1$ (1970), pp $1-13$.

3. Die Duitse aandeel in die militêre geskiedenis van Suid-Afrika en Suidwes-Afrika, 2/4 (1970), pp 1-25 (plus English and German translations, pp 26-72).

$\mathrm{BOUCH}$, R.J.

1. Medical Services in German South West Africa, 4/1 (1974), pp 58-62.

2. 6 SA Armoured Division in Italy, 4/2 (1974), pp 47-64.

3. Die uniform van die Transvaalse staatsartillerie, 4/3 (1974), pp 24-27.

4. 6 SA Armoured Division in Italy, 4/3 (1974), pp 58-73. 
5. The railways and the war effort, 1914-1915, 4/4 (1974), pp 1-14.

6. The action at Zoutpansdrift, 31 October 1914, 4/4 (1974), pp 42-47.

7. The railways and the war effort, 1939-1945, 5/2 (1975), pp 66-75.

8. The development of the Comptroller's Section, SADF, 1966-1976, 6/3 (1976), pp $1-5$.

\section{BOUWER, U.}

1. Die rol van die instrukteur in die moderne onderrig-leersituasie, 12/3 (1982), pp 54-60.

2. Geprogrammeerde onderrig: Skinner en Crowder se bydraes, 14/1 (1984), pp 19-25.

3. Huidige invloed en vooruitsigte van opvoedkundige tegnologie, 14/2 (1984), pp 49-56.

\section{BREDENKAMP, J.D.}

1. Die ontstaan en ontwikkeling van die Vloot, 1912-1982, 12/2 (1982), pp 31-37.

2. Die ontstaan en die ontwikkeling van die Kwartiermeester-Generaal, 12/2 (1982), pp 70-74.

3. The Archilles heel of the Soviet soldier, 13/4 (1983), pp 33-44.

4. The history of the Naval Mess (Union Hotel), Pretoria, 14/1 (1984), pp 14-18.

\section{BREEDT, J. V/D B.}

1. Ekonomiese prinsipes in verdediging, $7 / 1$ (1977), pp 18-23.

2. Die Suid-Afrikaanse oorlogsekonomie gedurende die Tweede Wêreldoorlog, (deel 1), 13/1 (1983), pp 46-66.

3. Die Suid-Afrikaanse oorlogsekonomie gedurende die Tweede Wêreldoorlog, (deel 2), 13/2 (1983), pp 1-18.

\section{BRINK, J}

1. Genl-Maj sir Henry Timson Lukin, 5/3 (1975), pp 40-51.

\section{BRINK, P.J.}

1. Short history of No 3 Squadron, SAAF, 2/1 (1970), pp 111-113.

2. Short history of No 15 Squadron, SAAF, 2/1 (1970), pp 114-117.

3. Short history of No 40 Squadron, SAAF, 2/1 (1970), pp 122-125.

\section{BRITS, L.}

1. The Chaplain-General, $12 / 2$ (1982), pp 75-79.
BROEKMAN, M.

1. Concord: verkry 'n houvas op personeel, 9/1 (1979), pp 24-26.

CHADWICK, G.A.

1. War graves registers, monuments headstones and crosses with special reference to the war of $1880-1881,11 / 1$ (1981), pp $31-39$.

CHAMBERS, $R$.

1. Art and propaganda in an age of war: the role of posters, 13/4 (1983), pp 54-59.

\section{COMBRINCK, J.A.}

1. Aardrykskunde (Geografie) as aangrensende wetenskap tot die Geskiedenis, 10/3 (1980), pp 40-47.

\section{CONRADIE, D.}

1. The Vierkleur and the Union Jack in the 1880-1881 war between the Zuid-Afrikaansche Republiek and Britain, 11/1 (1981), pp 58-61.

2. South Africa at war, 1912-1982, 12/2 (1982), pp 80-88.

3. Achievements of the SADF (1961-1982), $13 / 2$ (1983), pp 51-56.

4. Viëtnam: 'n bloedige leerskool, 14/1 (1984), pp 1-7.

\section{CONRADIE, G.}

1. The rules of International Law that regulate the use of interstate force, 12/1 (1982), pp $68-72$.

\section{CORNWELL, $R$.}

1. The Sanusi Campaign, 5/1 (1975), pp $1-33$.

2. South Africa and imperial naval defence, 5/4 (1975), pp 29-43.

3. 2 Anti-Tank Regiment, SAA- tank and antitank in the Western Desert, 1940-42, (part 1), 6/1 (1976), pp 37-51.

4. 12 Anti-Tank Regiment, SAA-tank and antitank in the Western Desert, 1940-42, (part 2), 6/2 (1976), pp 49-71.

5. 2 Anti-Tank Regiment, SAA- tank and antitank in the Western Desert, 1940-42, (part 3), 6/3 (1976), pp 24-48.

6. 2 Anti-Tank Regiment, SAA- tank and antitank in the Western Desert, 1940-42, (part 4), 6/4 (1976), pp 33-61.

7. Delville Wood: the South Africans in France, April-July 1916, 7/2 (1977), pp 1-55.

8. South African armoured car production in World War II, 7/3 (1977), pp 30-41. 
COSTER, K.R.

1. The training of Rhodesian officers at the Royal Military Academy, Sandhurst, 9/3 (1979), pp 53-57.

\section{COUSINS, F.A.M.}

1. Military music in South Africa: a critical study of its use in time of peace and its potential in time of war, together with constructive ideas for increasing efficiency, 11/3 (1981), pp 1-8.

\section{CROOK, L.A.}

1. Ubique - the gunners of South Africa, 13/3 (1983), pp 62-76.

\section{DALE, $R$}

1. The South African Armed Forces and their link with the United Kingdom and the Commonwealth of Nations, 1910-1961, 9/1 (1979), pp 1-11.

\section{DE BEER, F.C}

1. Die Weermag as ontwikkelingsinstrument in die Derde Wêreld, 8/4 (1978), pp 47-51.

2. Ontwikkelingsbehoeftes en administrasie, 11/4 (1981), pp 38-44.

DE JONG, C.

1. Verslae van neutrale militêre waarnemers tydens die Anglo-Boereoorlog, 4/1 (1974), pp 1-34.

2. Verslae van neutrale militêre waarnemers tydens die Anglo-Boereoorlog, 4/2 (1974), pp 1-12.

3. Verslae van neutrale militêre waarnemers tydens die Anglo-Boereoorlog, 5/1 (1975), pp 46-56.

4. Verslae van neutrale militêre waarnemers tydens die Anglo-Boereoorlog, 5/2 (1975), pp 54-65.

5. Reports of neutral military observers during the Anglo-Boer War, 5/3 (1975), pp 1-21.

6. Reports of neutral military observers during the Anglo-Boer War, 5/4 (1975), pp 49-59.

7. Reports of neutral military observers during the Anglo-Boer War, 1899-1902, 6/1 (1976), pp 52-56.

8. A biography of Robert de Kersauson, French volunteer with the Boer Commandoes, 6/2 (1976), pp 16-23.

9. A Fench volunteer in the ranks of the Boers, 6/4 (1976), pp 15-23.

DE JONG, R.C.

1. Die Slag van Bloedrivier, 16 Desember 1838, 9/1 (1979), pp 30-35.
DE VILLIERS, $P$.

1. The theory and application of regression analysis and the least-squares principle, 7/3 (1977), pp 50-56.

DIGBY, P.K.A.

1. Historical records of the 8th South African Infantry, 7/1 (1977), pp 57-65.

DODD, N.L.

1. UN peacekeeping operations, $12 / 4$ (1982), pp 57-65.

DORNING, W.A.

1. The West and the Cape Sea Route, 9/3 (1979), pp 46-52.

DUGMORE, P.B.G.

1. Organizational development in the South African Defence Force, 9/3 (1979), pp 64-69.

DU PLESSIS, L.

1. Die stryd teen die voorposte: 1-2 Februarie 1941, (deel 1), 4/4 (1974), pp 15-34.

2. Die stryd teen die voorposte: 1-2 Februarie 1941, (deel 2), 5/1 (1975), pp 57-75.

3. Die stryd teen die voorposte: 1-2 Februarie 1941, (deel 3), 5/2 (1975), pp 10-17.

DU PREEZ, S.

1. Die stryd teen oorlog: 'n Oorsig, 5/1 (1975), pp 34-39.

2. Rusland se geskenk aan 'n Boeregeneraal, 5/2 (1975), pp 27-43.

3. Die val van Pretoria, 5/3 (1975), pp 22-39.

4. Vliegopleidingskool Langebaanweg, 5/4 (1975), pp 28-15.

DU PLESSIS, T.A.P.

1. Die ontwikkeling van die SWA Weermag, 13/1 (1983), pp 28-34.

\section{DU TOIT, C.L. DE W.}

1. Herinneringe van Genl Christiaan Ludolph de Wet du Toit, (deel 1), 10/2 (1980), pp $7-24$.

2. Herinneringe van Genl Christiaan Ludolph de Wet du Toit, (deel 2), 10/3 (1980), pp $1-27$

3. Herinneringe van Genl Christiaan Ludolph de Wet du Toit, (deel 3), 10/4 (1980), pp $1-23$.

EBERLEIN, R.

1. A systems model for training, 9/1 (1979), pp 27-44) 
ERASMUS, D.R.

1. Ruimtelike beplanning: die rol van die stads- en streeksbeplanner in die SAW, 12/1 (1982), pp 27-31,

\section{FERREIRA, O.J.O.}

1. Die Staatsartillerie van die ZAR, 6/2 (1976), pp 1-15.

\section{FERREIRA, S.J.}

1. Die Suid-Afrikaanse Motorfietskorps, $8 / 3$ (1978), pp 11-19.

\section{FOURIE, D.F.S.}

1. Waar ontstaan ons militêre tradisies dan? 11/3 (1981), pp 35-37.

\section{FOXCROFT, E.}

1. Reports of neutral military observers during the Anglo-Boer War, 5/3 (1975), pp 1-21.

2. Reports of neutral military observers during the Anglo-Boer War, 5/4 (1975), pp 49-59.

3. England's war against the South African Republics, (translated from the Russian, and introduction by Mrs E. Foxcroft), (part 1), 11/4 (1981), pp 5-17.

4. England's war against the South African Republics, (translated from the Russian by Mrs E. Foxcroft), (part 2), 12/1 (1982), pp 44-57.

\section{GERBER, M.}

1. Iran in the internasionale magstryd, $9 / 3$ (1979), pp 7-23.

\section{GERTSCH, G.}

1. Artillery, 10/1 (1979), pp 28-40.

\section{GEYER, G.J.}

1. Liggaamlike opleiding in die Unie-verdedigingsmag (1912-1946), 2/3 (1970), pp $1-140$.

2. Historiese oorsig oor die ontwikkeling van sport in die SAW, 4/1 (1974), pp 71-88.

3. Die betekenis van sport as ' $n$ fisiese rekreatiewe aktiwiteit met besondere verwysing na die militêr, 9/4 (1979), pp 1-12.

\section{GLATTHAAR, L.}

1. Short history of No 41 Squadron, SAAF, 2/1 (1970), pp 126-128.

\section{GOMM, N.}

1. From the ship's log of HMSAS Imhof, $3 / 1$ (1971), pp 101-110.
GRASER, H.G.

1. The KGB: its composition, aims, and methods, 14/2 (1984), pp 9-22.

\section{GROBLER, J.E.H.}

1. Die Administratiewe Dienskorps, 7/3 (1977), pp 18-29.

2. Die Geallieerde besetting van Madagaskar in 1942, met spesifieke verwysing na die rol van die Unieverdedigingsmag in die operasies, (deel 1), 7/4 (1977), pp 1-1.8.

3. Die Geallieerde besetting van Madagaskar in 1942, (deel 2): die konsolodasietydperk Mei-Augustus 1942, 8/1 (1978), pp 39-54.

4. Die Geallieerde besetting van Madagaskar in 1942, (deel 3): die toetrede van die SuidAfrikaanse landmagte en die besetting van Tananarive, 8/2 (1978), pp 15-40.

5. Die Geallieerde besetting van Madagaskar in 1942, (deel 4): Tamatave, Tulear, en die oorgawe van Annet 8/3 (1978), pp 52-72.

6. Die Geallieerde besetting van Madagaskar in 1942, (deel 5): die lugoffensief, mediese aspekte en Vry Franse Oorname, $8 / 4$ (1978), pp 69-76.

HAINES, R.J.

1. The training of candidate officers in South Africa, 8/3 (1978), pp 1-10.

HARM, R.H.

1. Die ontwikkeling van die Sowjet-vloot sedert 1945, 9/4 (1979), pp 36-48.

HARMSE, $\mathrm{H}$.

1. 'n Opinie oor die Behaviouristiese siening versus die fenomenologie as grondslag vir effektiewe opleiding in weermagsverband, 11/2 (1981), pp 55-57.

HARRIS, C.J.

1. 'Yesteryear', 10/4 (1980), pp 35-38.

HATTING, D.L.

1. Rekenaarondersteunde onderrig in die Weermag, 11/4 (1981), pp 56-64.

HEITMAN, H.R.

1. The October 1973 Middle East war: a vindication of armour, 7/3 (1977), pp 1-17.

2. Some possibilities in counterinsurgency operations, $7 / 4$ (1977), pp 58-70.

3. Blitzkrieg inverted or the retiarius's net, $8 / 1$ (1978), pp 59-65.

4. The potential role of the military national development, 8/2 (1978), pp 1-11. 
5. The military glider revisited, 12/3 (1982), pp $42-50$.

6. The role of the NCO in the SADF, 13/4 (1983), pp 60-67.

HENNING, C.G.

1. The volunteer movement at Graaff Reinet (1856-1882), 3/6 (1973), pp 70-74.

2. Boerekrygsgevangenes in Ceylon, $4 / 3$ (1974), pp 1-14.

HOLLOWAY, J.E.

1. 'n Onwaarskynlike voorstel vir 'n ongelooflike spel, 14/1 (1982), pp 12-13.

\section{HUDSON, A.L.S.}

1. Infantry weapons in South Africa, 1652-1881, 10/2 (1980), pp 48-53).

2. The twentieth century development of different types of bacterial, biological and chemical weapons and the present capabilities of NATO and the Warsaw Pact in this respect, 13/4 (1983), pp 17-27.

\section{HUISAMEN, J.M.}

1. Wapenstilstandsdag, 8/3 (1978), pp 23-24

2. Afrikaans en die Eerste Vryheidsoorlog, 11/1 (1981), pp 40-44.

\section{JACOBS, F.J.}

1. Victoria Cross awards, $3 / 2$ (1972), pp 40-83.

2. Die Suid-Afrikaanse Leërkollege, 4/1 (1974), p 63-70.

3. Kleurlinge in militêre verband $4 / 2$ (1974), pp $39-46$.

4. 6 SA Armoured Division in Italy, 4/2 (1974), pp 47-64.

5. 6 SA Armoured Division in Italy, 4/3 (1974), pp 58-73.

6. 4 Field Regiment in East Africa, 1939-1941, 4/4 (1974), pp 48-57.

7. Anti-aircraft artillery in the Second World War, 7/1 (1977), pp 8-17.

\section{JACOBS, G.}

1. Non-alignment in Africa, 10/2 (1980), pp 25-34.

\section{JAPHET, M.}

1. Military coups and military regimes in Africa, 8/4 (1978), pp 1-12.

2. The international arms trade, $9 / 4$ (1979), pp 13-20.

3. Aspects of army road transport management, 10/4 (1980), pp 42-48.
JONKER, E

1. Die Militêr-Historiese en Argivale Dienste van die Departement van Verdediging $1 / 1$ (1969), pp 3-26.

2. Ontstaan en ontwikkeling van die Transvaalse Verdedigingsmag: Transvaal Volunteers, 3/3 (1972), pp 1-75.

KIRSTEN, J.F.J.

1. Die plek van die Swaardmagorganisasie (Weermag) in die Staatsbestel, 9/1 (1979), pp 12-16.

KOTZE, H.A.

1. 'n Nuwe perspektief op die saamleef van soldate, 13/3 (1983), pp 54-57.

KOTZE, J.C.

1. Calueque en Cabora-Bassa: ekonomiese bates of politieke waagstukke, 7/1 (1977), pp 45-56.

2. Mngazana - 'n nuwe hawe vir die Transkei, 8/3 (1978), pp 25-32.

\section{KOTZE, J.S.}

1. Nazi interne propaganda in die Tweede Wêreldoorlog, 7/3 (1977), pp 42-49.

KROUKAMP, W.

1. Lt A.W. Beauchamp-Proctor - die klein mannetjie met die leeumoed, 14/1 (1984), pp 29-31.

2. Sersant Quentin George Murray Smythe - 'n man van durf en daad, 14/2 (1984), pp $23-24$.

3. Die Nasionale Vlag van die Republiek van Suid-Afrika, 14/2 (1984), pp 25-29.

4. Lt-kdr D.A. Hall, die groothartige skipper, 14/4 (1984), pp 40-43.

\section{LAWRENCE, G.G.J.}

1. Echoes of war, 1915-1918, (part 1), 8/1 (1978), pp 1-21.

2. Echoes of war, 1915-1918, (part 2), 8/2 (1978), pp 42-55.

3. Echoes of war, 1915-1918, (part 3), 8/3 (1978), pp 37-51.

4. Echoes of war, 1915-1918, (part 4), 8/4 (1978), pp 56-68.

\section{LE GRANGE, S.C.}

1. Die geskiedenis van Hoof van Staf Inligting, $12 / 2$ (1982), pp 56-58.

2. Die geskiedenis van Hoof van Staf Operasies, 12/2 (1982), pp 59-61. 
LE ROUX, A.M.

1. Die rol van Kleurlinge in Suid-Afrika se militêre verlede, 14/4 (1984), pp 52-61.

LILLIE, A.C.

1. The origin and development of the South African Army, 12/2 (1982), pp 7-17.

2. Chief of Staff Finance, 12/2 (1982), pp 67-69.

3. An alternative view of South African Artillery, 13/1 (1983), pp 38-45.

4. South African artillery in the eighties, 14/2 (1984), pp 32-34.

LITTLE, I.C.

1. Why not a supermarket navy?, 11/2 (1981), pp 21-27.

\section{LOEDOLFF, P.}

1. Opvoedkundige tegnologie in die SAW, $8 / 4$ (1978), pp 80-81.

2. Onderriglyne vir volwasse onderrig, $8 / 4$ (1978), pp 82-91.

3. Die faktore wat leersukses bevorder, $9 / 4$ (1979), pp 65-70.

4. Die oorsprong en ontwikkeling van die onderrigfilm, 10/1 (1980), pp 41-47.

LOMBAARD, B.V.

1. Die Longtomkanonne na die Slag van Dalmanutha, 14/4 (1984), pp 21-26.

\section{LOUBSER, J.}

1. SADF early iron age excavations in the Tugela valley, 14/4 (1984), pp 27-39.

\section{MALONE, E.M.}

1. The hunter of man, 13/1 (1983), pp 24-27.

MEYER, A.C.

1. The history of $27 \mathrm{~b}$ Squadron SAAF, $4 / 3$ (1974), pp 51-57.

\section{MEYER, C.M.}

1. Missiles and Aircraft, (part 1), 8/4 (1978), pp 31-39.

2. Missiles and Aircraft, (part 2), 9/1 (1979), pp 17-23.

3. Missiles and Aircraft, (part 3), 9/3 (1979), pp 58-63.

4. Missiles and Aircraft, (part 4), 9/4 (1979), pp 58-64.

5. The deployment of Soviet chemical forces in Afghanistan and South-East Asia, 14/1 (1984), pp 8-11.

6. Soviet aims in Southern Africa: economic considerations, 14/2 (1984), pp 45-48.
MEYERS, E.M.

1. Die ontwikkeling van die vrou as soldaat, 11/2 (1981), pp 13-20.

2. Aanpassingsprobleme in die militêre milieu, 12/1 (1982), pp 58-67.

3 . Voorgeskiedenis tot die stigting van 'n Verdedigingsmag, 12/2)1982), pp 1-6.

4. Leiers deur die jare (1912-1982), 12/2 (1982), pp 89-99.

5. Die rol van moreel in die militêre konflik, $13 / 1$ (1983), pp 16-23.

6. Elemente van revolusie, 13/2 (1983), pp 34-50.

7. Die vrou in uniform: standpunte en beskouinge, 13/3 (1983), pp 23-33.

8. Die Suid-Afrikaanse soldaat: ' $n$ historiese profiel, 14/2 (1982), pp 35-44.

MONICK, S.

1. The twilight conflict: operations in the Radfan, May-June 1964, 8/4 (1978), pp 19-27.

2. The fire act tragedy: the French in IndoChina, 11/2 (1981), pp 1-12.

3. Victory in Hades: the forgotten wars of the Oman, 1957-1959 and 1970-1976, (part 1), 12/3 (1982), pp 1-24.

4. Victory in Hades: the forgotten wars of the Oman, 1957-1959 and 1970-1976, (part 2), the Dhofar campaign, 1970-1976, 12/4 (1982), pp 1-26.

5. Victory in Hades: the forgotten wars of the Oman, 1957-1959 and 1970-1976, (part 2), the Dhofar campaign, 1970-1976, 13/1 (1983), pp 1-15.

MOORCRAFT, P.L.

1. Clausewitz and Sandhurst: Officer training in Britain, 8/1 (1978), pp 24-32.

2. Guns before politics, $8 / 2$ (1978), pp 12-14.

MOORE, D.M.

1. SAAF in Korea, 10/4 (1980), pp 24-34.

NEL, H.F.

1. Die rol van die seemag in Duits Suidwes-Afrika, 1914-1915, 7/2 (1977), pp 56-65.

NELSON, C.

1. Propaganda: dodelike wapen van die kommunisme, 7/2 (1977), pp 70-78.

2. The role of sea power in the Soviet Union's strategy for world domination, 8/2 (1978), pp 67-74.

NORTH, J.W.

1. South African Army Postal Services, 1940-1946, 2/6 (1970), pp 1-51. 
NORTIER, D.

1. 7 Squadron in World War II, 1942, (part 1), 5/2 (1975), pp 1-9.

2. 7 Squadron in World War II, 1943-1945, (part 2), 5/3 (1975), pp 52-65.

3. Post war history of No 7 Squadron, (part 3), 5/4 (1975), pp 44-48.

NÖTHLING, C.J.

1. Requiem vir die tenk: ab initio ad finem, $10 / 4$ (1980), pp 49-55.

2. Military commanders of the war (18801881), 11/1 (1981), pp 76-80.

3. Die rol van militêre faktore in die konsipiëring van neutraliteit as verdedigingsbeleid, 11/2 (1981), pp 47-54.

4. Die helikopter as troepedraer in konvensionele lugoperasies, 12/1 (1982), pp 1-9.

5. Leiers deur die jare (1912-1982), 12/2 (1982), pp 89-99.

6. Kardinale aspekte van Nasionale Diensplig met spesifieke verwysing na Suid-Afrika, 12/3 (1982), pp 32-41.

7. Die Inspekteur-Generaal in die Suid-Afrikaanse Weermag, 1912-1983, 13/2 (1983), pp 57-65.

8. Die slag van Doornkraal, $13 / 4$ (1983), pp $1-16$.

\section{OBERHOLZER, J.J.}

1. John Weston, the grandfather of aviation in South Africa, 3/6 (1973), pp 1-52.

2. Some South African firsts in aerial flight, $3 / 6$ (1973), pp 53-55.

3. List of documents on early aviation in the collection of the National Museum, Bloemfontein, 3/6 (1973), p 56.

OTTO, W.

1. Boeregewere uit twee Vryheidsoorloë, 4/2 (1974), pp 18-25.

2. Grepe uit 'n kleurryke artillerietradisie, 4/4 (1974), pp 35-41.

3. Infanterie in Suid-Afrika, 5/1 (1975), pp $40-45$.

4. Die Direktoraat Openbare Betrekkinge gedurende Wêreldoorlog II, 5/2 (1975), pp $18-25$.

5. Pantser, 5/4 (1975), pp 16-19.

6. Kinders in militêre verband, $6 / 1$ (1976), pp 31-36.

7. Is bajonette uitgedien? 6/2 (1976), pp 24-29.

8. Net treffers tel, 6/3 (1976), pp 49-54.

9. Epiloog/Epilogue, 9/2 (1979), p 40.

10. C.F. Louis Leipoldt (28 Des $1880-12$ April 1947), 9/4 (1979), pp 5-57.
11. Die slag van Majuba, 27 Februarie 1881, 11/1 (1981), pp 1-7.

12. Outeurskap van 'historiese opstelle', 11/3 (1981), pp 45-46.

13. Proklamering van Greefswald 37 MS Zoutpansberg tot 'n Nasionale Gedenkwaardigheid, 13/3 (1983), pp 58-60.

PARDOE, G.R.

1. Nigeria's return to civilian rule: an assessment of corrective military government, 10/3 (1980), pp 28-39.

\section{PARKINS, N.C.}

1. Instructional media 13/2 (1983), pp 70-74.

PICKARD, J.H.

1. Translating technical service prose, 10/1 (1980), pp 9-15.

2. Hoekom vertaal?, 11/4 (1981), pp 1-4.

\section{PLOEGER, J.}

1. Hoofstukke uit die voor- en vroeë geskiedenis van die SAW, 1/3 (1969), pp 1-87.

2. Op Brandwag - drie eeue militêre geskiedenis van Suid-Afrika, 1/4 (1969), pp 4-47.

3. Suid-Afrikaanse Verdedigingskemas, 1887-1914, 1/5 (1969), pp 1-96.

4. Die opleiding van ons eerste vlieëniers, 2/1 (1970), pp 14-35.

5. Die Zuid-Afrikaanse Vliegeniers Korps: vliegtuie en personeel vir en in Suidwes, 1914-1915, 2/1 (1970), pp 26-67.

6. 26-Eskader RFC, 2/1 (1970), pp 68-87.

7. South African Air Force. Nominal roll of officers, air WO's, air NCO's and airmen, 2/1 (1970), pp 88-94.

8. Twee Duitse vliegtuie van Duala, 2/1 (1970), pp 95-109.

9. Besonderhede aangaande ' $n$ aantal geboue op die terrein van die huidige verdedigingshoofkwartier, Potgieterstraat, Pretoria, 2/2 (1970), pp 1-25.

10. Die Kasteel 'De Goede Hoop', 1921-1923, die verhaal van 'n reddingsdaad, 2/2 (1970), pp 26-46.

11. Die militêre boukuns in die Nederlande en sy eertydse kolonies 2500-1800, 2/2 (1970), pp 47-59, (plus English translation), pp 60-71.

12. Die Duitse andeel in die militêre geskiedenis van Suid-Afrika en Suidwes-Afrika, 2/4 (1970), pp 1-25, (plus English and German translations), pp 26-72.

13. The South African Field Post and Telegraph Corps, 1914-1915, 2/5 (1970), pp 1-73.

14. Notes on the 6th South African Armoured 
Division Postal Unit, 2/6 (1970), pp 69-74.

15. Uit die voorgeskiedenis van die Suid-Afrikaanse vloot: die ontstaan van die Suid-Afrikaanse Seediens, 3/1 (1971), pp 1-80.

16. Suid-Afrika en die Imperiale Generale Stafgedagte, 3/2 (1972), pp 1-18.

17. Die Imperiale militêre beleid ten opsigte van Suid-Afrika, 1908-1910, 3/2 (1972), pp 19-29.

18. Duitse amptelike korrespondensie in verband met die verdediging van en fortebou in die Zuid-Afrikaansche Republiek, 3/2 (1972), pp 30-39.

19. Victoria Cross awards, $3 / 2$ (1972), pp 40-83.

20. Nederlandse 'Springbokke' en die Brigade. 'n Bydrae tot die geskiedenis van die 'Koninklike Nederlandsche Brigade 'Prinses Irene', 3/4 (1972), pp 1-103.

21. Die fort te Johannesburg, $3 / 5$ (1972), pp $1-60$.

22. Die Nasionale Vlag en die vlaghuising op 31 Mei 1928, 3/5 (1972), pp 61-73.

23. Flights by foreign civil aircraft to South Africa, 3/6 (1973), pp 57-68.

24. Verslae van neutrale militêre waarnemers tydens die Anglo-Boereoorlog. 4/1 (1974), pp 1-34.

25. The action at Sandfontein, 26 September 1914, 4/1 (1974), pp 35-50.

26. The skirmish at Grassplatz, 26 September 1914, 4/1 (1974), pp 51-54

27. Aircraft which nearly entered the war, 1914-1915, 4/1 (1974), pp 55-57.

28. Verslae van neutrale militêre waarnemers tydens die Anglo-Boereoorlog, 4/2 (1974), pp 1-12.

29. Kleurlinge in militêre verband, 4/2 (1974), pp 39-46.

30. Die oorgawe van Johannesburg, 31 Mei 1900, 4/3 (1974), pp 15-23.

31. Arbitrasie tydens die Anglo-Boereoorlog, 5/2 (1975), pp 44-53.

32. Die krygsplan van Staatsprokureur J.C. Smuts, 6/1 (1976), pp 27-30.

33. Die Geskiedenis van die gedenkteken ter gedagtenis aan heengegane geïnterneerdes in Portugal, 11/3 (1981), pp 30-34.

34. Die bou van die Staatsartilleriekaserne, Potgieterstraat, Pretoria: die uitbreiding in 1924 om die Hoofkwartier van die Univerdedigingsmag te huisves, 13/4 (1983), pp 28-32.

35. Monumente ter gedagtenis aan Lt-kol Henning P.N. Pretorius, $1844-1897$ in die Transvaalse hoofstad, 14/1 (1984), pp 32-36.
PRETORIUS, C.M.L.

1. Die SAGD - sy ontstaan en ontwikkeling, 12/2 (1982), pp 38-45.

RICE, W.H.

1. The harbour defence motor launches, $8 / 4$ (1978), pp 28-30.

2. Air/Sea rescue launches, $8 / 4$ (1978), pp $52-55$.

ROBERTSON, D.C

1. UCT in uniform, 10/1 (1979), pp 23-27.

ROBINSON, R.

1. 7 Squadron in World War II, 1942, (part 1), 5/2 (1975), pp 1-9.

2. 7 Squadron in World War II, 1943-1945, (part 2), 5/3 (1975), pp 52-65.

3. Post war history of No 7 Squadron, (part 3), 5/4 (1975), pp 44-48.

ROMEIKO-GURKO, V.I.

1. England's war against the South African Republics, (translated from the Russian and introduction by Mrs E. Foxcroft), (part 1), 11/4 (1981), pp 5-17.

2. England's war against the South African Republics, (translated from the Russian by Mrs E. Foxcroft), (part 2), 12/1 (1982), pp $44-57$

ROOTHMAN, A.W.L.

1. Die gebruik van terrorisme as ' $n$ internasionale politieke bedingingsinstrument, 11/3 (1981), pp 52-57.

\section{SCHEEPERS, C.C}

1. Die Suid-Afrikaanse stad as ruimtelike basis vir 'n insurgente staat, 12/4 (1982), pp $47-56$.

SENEKAL, A.

1. Die aard, totstandkoming en ontwikkelingsverloop van die militêre sosiologie met verwysing na enkele navorsingsoorwegings, 12/4 (1982), pp 27-40.

SHAW, A.D.

1. The military as a contributor to national development, 9/3 (1979), pp 38-45.

2. Veelvolkige gewapende magte: probleme en oplossings, 10/1 (1980), pp 1-8.

3. Command, control and communications, 10/3 (1980), pp 48-60.

SHELVER, R.L.

1. The Civil War: birthplace of the new navy, 8/1 (1978), pp 66-70. 
SMIT, J.P.

1. Die dood van generaal De la Rey, 6/3 (1976), pp 6-23.

\section{STEENKAMP, J.A.}

1. Die Vrystaatse vrywillige militêre eenhede 1854-1899, 10/1 (1980), pp 16-22.

\section{STEENKAMP, W.P.}

1. Some medical impressions of Abyssinia, 4/3 (1974), pp 28-35.

\section{STOFFBERG, D.P.}

1. Die invloed van marxisme en kommunisme op die tradisionele swart gemeenskappe van Afrika, 14/4 (1984), pp 1-4.

2. SADF early iron age excavations in the Tugela Valley, 14/4 (1984, pp 27-39.

\section{STRYDOM, D}

1. Die grafiese voorstelling van stroomlyne van 'n Goukowski-profiel met behulp van 'n rekenaar, 8/3 (1978), pp 33-36.

\section{SWART, F.H.}

1. Hoe doeltreffend is die internasionale vredesmagte?, 14/4 (1984), pp 44-51.

SWIFT, M.

1. The Union Defence Force Entertainment Group in South Africa (World War II), 14/2 (1974), pp 26-38.

2. The Union Defence Force Entertainment Group in the Middle East, 4/3 (1974), pp $36-50$

\section{TANCRED, $P$.}

1. Weer en klimaat as omgewingsfaktore in die militêre situasie, 8/1 (1978), pp 33-38.

\section{TAYLOR, A.}

1. Short notes on lasers and their military applications, 7/4 (1977), pp 55-57.

\section{THERON, P.}

1. The deployment of Soviet chemical forces in Afghanistan and South-East Asia, 14/1 (1984), pp 8-11.

USHER, H.J.

1. British Army Commissions by purchase, $8 / 4$ (1978), pp 77-79.

2. The charge of the Light Brigade and South Africa's very own pony, 14/1 (1984), pp 26-28.

\section{VAN DEVENTER, A.J.}

1. Foreword, 9/1 (1979), p I.
VAN DRIEL, A.

1. The role and utility of military power, $11 / 4$ (1981), p 54-55.

VAN JAARSVELDT, A.E.

1. Militêre geneeskunde gedurende die vroeë jare, (deel 2), 7/1 (1977), pp 24-44.

2. Die Warskou-debakel (met spesiale verwysing na die Suid-Afrikaanse Lugmag se rol), 7/4 (1977), pp 19-37.

3. Die Suid-Afrikaanse Militêre Verplegingsdiens, 8/2 (1978), pp 56-66.

4. Pretoria gedurende die Eerste Vryheidsoorlog, 11/1 (1981), pp 45-57.

\section{VAN LOGGERENBERG, J.P.B.}

1. Some aspects of training at military academies, 7/1 (1977), pp 1-7.

2. 'n Oorsig van die SALT-ooreenkomste, $8 / 1$ (1978), pp 55-58.

VAN NIEKERK, M.J.

1. Lugkrag in die RSA, 10/2 (1980), pp 41-47.

VAN RENSBURG, T.

1. Ontwikkelingsaspekte van kernmissiele, 12/1 (1982), pp 35-43.

2. Die strategiese kernvloot en kernlugvermoë, 12/3 (1982), pp 25-31.

VAN TONDER, A.G.W.

1. Die beleg en ontsetting van Ladysmith, $8 / 3$ (1978), pp 73-79.

VAN TROMP, J.

1. Dronkenskap in die Suid-Afrikaanse Weermag na aanleiding van artikel 33 a van die Reglement van Dissipline, 7/4 (1977), 71-75.

VRUGTMAN, J.

1. The voyage of the Gelderland, 11/3 (1981), pp 20-29.

WAGNER, $N$.

1. NATO and the Warsaw Pact, $8 / 4$ (1978), pp 40-46.

WARD, D.W.

1. American cruise missiles, $8 / 3$ (1978), pp 20-22.

WARD, E.H.

1. Swifter than eagles: a brief history of the South African Air Force, 1912-1982, $12 / 2$ (1982), pp 18-30. 
2. The Defaqne - socio-military revolution and demographic determinant, 13/3 (1983), pp 34-53.

\section{WESSELS, A.}

1. Die Suid-Afrikaanse Vloot: verlede, hede, toekoms: 'n kort kritiese evaluering, (deel 1), 11/3 (1981), pp 9-19.

2. Die Suid-Afrikaanse Vloot: verlede, hede, en toekoms (deel 2), 11/4 (1981), pp 18-28.

\section{WESSELS, P.W.}

1. The siege of Jammerbergdrift: April 6-25, 1900, 14/4 (1984), pp 63-66.

VAN WYK, J.

1. Die Unieverdedigingsmagte op die vooraand van die Tweede Wê reldoorlog, 1934-1939, 6/4 (1976), pp 24-32.

VAN ZYL, A.E.

1. Die Sleutelseremonie van Gibraltar, $5 / 4$ (1975), pp 20-28.

2. 3 Field Squadron, SAEC, (part 1), 6/1 (1976), pp 1-26.

3. 3 Field Squadron, SAEC, (part 2), 6/2 (1976), pp 30-48.

4. Militêre geneeskunde gedurende die vroeë jare, (deel 1), 6/4 (1976), pp 1-14, (for subsequent publications, see under VAN JAARSVELDT A.E.).
VERBEEK, P.O.

1. Mosambiek: die ontwikkeling van die insurgente staat, 7/2 (1977), pp 66-69.

VISSER, G.E.

1. Die Middellandse Regiment, $8 / 4$ (1978), pp $13-18$.

2. Die Eerste Vryheidsoorlog: enkele aspekte mbt die Britse siening van die Boere en die verskille tussen Boer en Brit, 11/1 (1981), pp $69-75$.

VIVIER, F.J.

1. 'n Ontleding van die invloed en vermoë van kortafstandlugvervoersteun op eenheidstaktiese beplanning en operasies en aanbevelings hoe hierdie steun tot die maksimum benut kan word, 11/2 (1981), pp 28-37.

VLOK, T.C.B.

1. The application of radar in the UDF during World War II, 4/2 (1974), pp 13-17.

VON MOLTKE, R.

1. Wapentuig van die Eerste Vryheidsoorlog, 11/1 (1981), pp 8-30.

2. Die ontstaan en ontwikkeling van die stafafdeling Hoof van Staf Personeel, 12/2 (1982), pp 46-51. 